\title{
COMPARATIVE STUDY OF THE EFFECT OF GAMMA-RADIATION ON THE STRUCTURAL AND THERMOPHYSICAL PROPERTIES OF NITRILE-BUTADIENE RUBBER FILLED WITH DIFFERENT NANOMETAL OXIDES
}

\author{
R.F. Khankishiyeva, S.M. Mammadov, H.N. Akhundzada, \\ J.S. Mammadov, A.I. Azadaliyev, P.I. Ismayilova, G.A. Mammadova \\ Institute of Radiation Problems, Azerbaijan National Academy of Science, Baku, Azerbaijan \\ E-mail: r.khankishiyeva@irp.science.az
}

In the present work, the structure and thermal properties of nanocomposites based on nanometal oxides $(\mathrm{ZnO}$, $\mathrm{Al}_{2} \mathrm{O}_{3}, \mathrm{ZrO}_{2}$ ) and aromatic disulphochloride benzene compounds in a butadiene nitrile rubber (NBR) matrix that are obtained by gamma-rays processing have been investigated. Structural changes of nanocomposites depend on the type of used nanoparticles which have been identified by Fourier Transform Infrared (FTIR) spectroscopy and Electron Paramagnetic Resonance (EPR). Analysis by Scanning Electron Microscope (SEM) was used to study the morphology phase of the nanoparticles in the polymer matrix and the interface between the polymer-filler. In addition, the results of the samples based on NBR were obtained by thermogravimetric analysis (TGA)/differential thermal analysis (DTA). The results show that, the thermal stability of nanocomposites significantly decreased after irradiation, but with the addition of a certain amount of benzene-1,3-disulfonyl chloride (DSChB) and nanometal oxides to rubber blend the thermal stability could be improved.

PACS: 34.50.Lf 72.80.Tm 78.67.Sc

Nanotechnology is one of the interesting areas in technology that will impact to the most of the industry sectors and contribute to novel materials, devices and products. In the global market, the demand for such materials is rapidly increasing, and the proposals that are able to satisfy the ever-increasing demands of designers and technologists for expanding the range of products for various purposes are not enough, which contributes to the intensive development of research in this area [1].

A new direction in the creation of polymer composite materials is nanopolymer materials since the properties of composite materials exceed the properties of its individual phases.

For the polymer nanocomposites, nanoparticles are used as the second phase, and it is necessary to take into account the size and topology of the surface of these particles. Nanocomposites which are based on ceramics and polymers combine the qualities of all the constituent components: flexibility, elasticity, wear resistance, the process ability of polymers and for glass hardness and high refractive index characteristic. As a result, many properties of materials are improved in comparison with the initial components [2].

It is known that the reaction of the polymer with the nanoparticles is done with two different fundamentally ways - physical or chemical. It is not only important the presence of certain reactive functional groups in the polymer, but their intensive interaction with the surface atoms of the nanoparticles is also important as well.

In systems based on insoluble polymers, the processes of obtaining nanocomposites are significantly complicated due to the diffusion of reduced ions in the polymer matrix [3]. The size and distribution of the generated nanoparticles depend on the interaction conditions and parameters of the porous structure of the polymer and a little bit on the nature of the nanoparticles.
The interaction of the filler with rubber is a key parameter in the hardening of elastomers. Good dispersion of the filler in the vulcanizate is very important because it affects the interaction of the rubberfiller and consequently, the final properties of the elastomeric material. However, these additives lead to insignificant effects and may impair the properties of the material.

Many scientists use nanosized fillers, such as carbon black, calcium carbonate and talc [4-6]. The influence of natural fillers, such as clay and beach sand, on some properties of fillers in polymer systems have also been investigated [7-11].

Inorganic nanoparticles are most widely used in various compositions based on rubbers and vulcanizates. Currently, nanoparticles of metal oxides, $\mathrm{SiO}_{2}, \mathrm{TiO}_{2}$, $\mathrm{ZnO}, \mathrm{MnO}_{2}, \mathrm{Al}_{2} \mathrm{O}_{3}$, and $\mathrm{ZrO}_{2}$ are in great demand as fillers for nanocomposite materials [12-16].

It was found that, when the content of nanoparticle fillers is in the amount of 0.4 to $1.0 \mathrm{phr}$ of $100 \mathrm{phr}$ rubber, there is a noticeable increase in tensile strength at break and abrasion resistance. These data are similar to that which was observed when adding 3-5 parts by weight of active macrosized fillers [17].

There are number of researches which are related to preparation of elastomeric composites with usage of nanosized powders of metal oxide. The objectives of these researches are to maximize improvement of the properties of polymer composites based on polyethylene, polypropylene, methyl methacrylate.

Because of its interesting properties, $\mathrm{ZnO}$ has been widely used in elastomeric industry as an activator for natural and synthetic rubbers, as well as for some groups, like $-\mathrm{Cl},-\mathrm{COOH}$, etc. Although, many researchers have proposed to use of nanosized powders of $\mathrm{ZnO}$, has a pronounced effect on the speed of vulcanisation and on the distribution of crosslinks formed [19]. 
Interesting results are given in nanocomposites based on carboxyl-nitrile rubber in which obtained rod-shaped $\mathrm{ZnO}$ nanoparticles. The study of such materials showed that the nanoparticles of zinc oxide, compared with the bulk material of the same composition contribute to an increase in the rate of sulfur vulcanization and to an improvement in the mechanical properties of the obtained samples [20].

Some modern scientists investigated systematic changes in physical parameters such as the glass transition temperature, specific heat capacity and thermal stability of nanocomposites based on NBR and $\mathrm{ZrO}_{2}$ nanopowder, compared to pure NBR. It was revealed that reinforcing filler $\mathrm{ZrO}_{2}$ have excellent properties as the ability to increase the viscosity, surface hardness and tensile strength of the composite.

Scientists have found that the incorporation of silicon dioxide nanoparticles into acrylonitrile butadiene/chlorosulphonated polyethylene rubber blends (NBR/CSM) based rubber compounds during radiation exposure and it is resulted in an increase in tensile strength, elongation at break and modulus of tensile elasticity. The inclusion of silicon dioxide in NBR improves its insulating properties [21].

However, nanoparticles tend to agglomerate in their natural state and for this reason the effective distribution of nanoparticles in the elastomeric matrix has become a problem. It was established that, immiscible polymer blends, which were filled with various types of nanosized additives, did not form a chemical bond between rubber molecules and nanoparticles. Consequently, these kinds of particles act only as a physical modifier and do not have a significant effect on the properties of vulcanizates.

To solve this problem, scientists are developing new technologies for dispersing and stabilizing nanoparticles in a polymer matrix [22]. Technology of radiation modification of elastomers and their mixtures allows obtaining nanocomposites, with new chemical bonds, as well as, significantly improves the characteristics of the matrix with a small concentration of filler. In comparison with the known thermochemical methods of vulcanization, the radiation method is characterized by a number of advantages; firstly, it provides for the production of elastomeric products using more modern technology and, secondly, as a result of changing the chemical structure grid and density of rubber allows obtaining products with improved and new properties.

It is well known that NBR is a type of crosslinked rubber when exposed to high energy radiation and is widely used in the manufacture of rubber technical products with high strength properties, since the nitrile groups of NBR have the ability to resonantly stabilize the free radical formed upon detachment of a hydrogen atom after irradiation and at the expense of macroradicals forms cross-links. It is also possible that the nitrile groups can participate in the crosslink process itself [23].

This study aims to improve the thermophysical characteristics of an elastomeric composite based on NBR, through the development of radiation crosslinking technology. As an activator, nanopowders of oxides, such as zinc oxide, aluminum oxide, and zirconium oxide and with the participation of a chlorine-preparing cross-linking agent, are used.

\section{EXPERIMENTAL DETAILS}

\subsection{MATERIALS}

Acrylonitrile butadiene rubber (commercial name SKN-40), containing $40 \mathrm{wt} . \%$ acrylonitrile was obtained from Russia. The Mooney viscosity was ML1+4 $\left(100{ }^{\circ} \mathrm{C}\right): 47$. In the process, as a crosslinking agent used the aromatic compounds benzene-1,3disulfonyl chloride (DSChB), which reacts readily with NBR macromolecules.

DSCB is an organosulfur compound with the formula $\mathrm{C}_{6} \mathrm{H}_{5}\left(\mathrm{SO}_{2}\right)_{2} \mathrm{Cl}_{2}$ and it is a colorless viscous oil that dissolves in organic solvents but reacts with compounds containing reactive $\mathrm{N}-\mathrm{H}$ and $\mathrm{O}-\mathrm{H}$ bonds. The processed naphthenic oil was used as a plastificator [24].

The nanomaterials have been obtained from the Inc. Houston, TX, USA. The physical and chemical properties of nanopowders are summarized in Table 1.

Table 1

The physical and chemical properties of nanopowders

\begin{tabular}{|c|c|c|c|}
\hline \multirow{2}{*}{ Characteristic } & \multicolumn{3}{|c|}{ Metal nano oxides } \\
\cline { 2 - 4 } & $\mathrm{ZnO}$ & $\mathrm{Al}_{2} \mathrm{O}_{3}$ & $\mathrm{ZrO}_{2}$ \\
\hline Molecular weight, g/mol & 81.4 & 101.96 & 123.2 \\
\hline Particle size, $\mathrm{nm}$ & $20 \ldots .25$ & $40 \ldots 50$ & $20 \ldots .30$ \\
\hline Specific surface, $\mathrm{m}^{2} / \mathrm{g}$ & 250 & 180 & 160 \\
\hline True density, $\mathrm{g} / \mathrm{cm}^{3}$ & 5.606 & 2.9 & 5.89 \\
\hline $\begin{array}{c}\text { Dispersibility of the } \\
\text { nanoparticles, } \%\end{array}$ & $>99.2$ & $>99.9$ & $>99.9$ \\
\hline
\end{tabular}

\subsection{PREPARATION OF COMPOSITES}

Nanocomposites based on NBR were prepared on two roll-mixing mills (outside diameter $470 \mathrm{~mm}$, working distance $300 \mathrm{~mm}$, speed of slow roll $24 \mathrm{rpm}$ and friction ratio of $(1: 1.4)$ in accordance with ASTM D3182-07. First, NBR (100 phr) was masticated for 2 min followed by the addition of nanopowders of metal oxides and DSChB (Table 2).

Formulations for NBR

Table 2 nanocomposites

\begin{tabular}{|c|c|c|c|c|c|c|}
\hline \multirow{2}{*}{ Compounds } & \multicolumn{6}{|c|}{ phr } \\
\cline { 2 - 7 } & \multicolumn{3}{|c|}{ Non-irradiated } & \multicolumn{3}{c|}{$\begin{array}{c}\text { Irradiated } \\
(D=250 \mathrm{kGy})\end{array}$} \\
\cline { 2 - 7 } & $\mathrm{N} 1$ & $\mathrm{~N} 2$ & $\mathrm{~N} 3$ & $\mathrm{~N} \mathrm{4}$ & $\mathrm{N} 5$ & $\mathrm{~N} \mathrm{6}$ \\
\hline $\mathrm{NBR}$ & 100 & 100 & 100 & 100 & 100 & 100 \\
\hline $\mathrm{ZnO}$ & 3.0 & - & - & 6.0 & - & - \\
\hline $\mathrm{Al}_{2} \mathrm{O}_{3}$ & - & 3.0 & - & - & 3.0 & - \\
\hline $\mathrm{ZrO}_{2}$ & - & - & 3.0 & - & - & 3.0 \\
\hline $\mathrm{DSChB}$ & 3.0 & 3.0 & 3.0 & 3.0 & 3.0 & 3.0 \\
\hline $\begin{array}{c}\text { Naphthenic } \\
\text { oil }\end{array}$ & 5.0 & 5.0 & 5.0 & 5.0 & 5.0 & 5.0 \\
\hline
\end{tabular}

Compounds were finally sheeted again in the rolling direction into slabs of about $0.2 \mathrm{~mm}$ thickness and the sheets were pressed in clean molds of a hydraulic press. The molds were brought to $423 \mathrm{~K}$ and held at this temperature for $10 \mathrm{~min}$ at a pressure of $100 \mathrm{~atm}$.

The samples were placed in a $1 \mathrm{~g}$ vial of glass evacuated for $1.3 \mathrm{~h}$ and $10^{-1} \mathrm{~Pa}$ residual pressure for the irradiation. The radiochemical processing was performed 
in air at room temperature, inside of the $\operatorname{Co}^{60} \gamma$-radiation source at a dose rate of about $4.9 \mathrm{kGy} / \mathrm{h}$.

Irradiation of samples was carried out at the Institute of Radiation Problems, Azerbaijan. The absorption of current samples was calculated by comparing the electron densities of the investigated dosimeter systems. The simplified radiation vulcanization process is shown step by step as a scheme in the following Fig. 1.

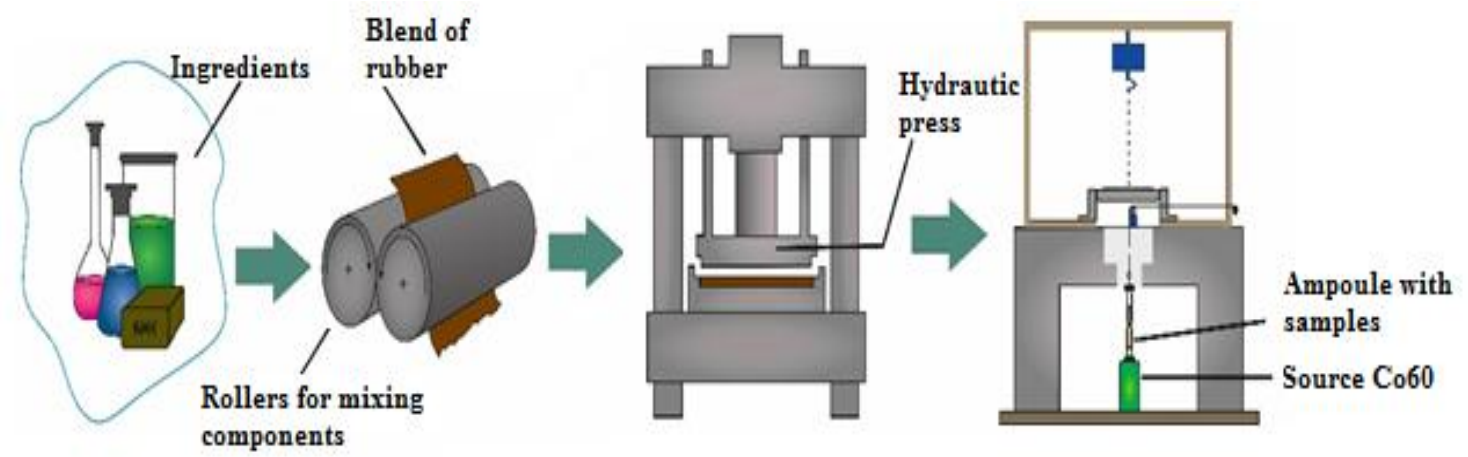

Fig. 1. Scheme of the process of irradiation vulcanization spectrometer of the VARİAN 640 FT-IR in the range of $4000 \ldots 400 \mathrm{~cm}^{-1}$. The samples for analysis were made in the mold in the form of a film without any additives. The thickness of film is $0.2 \ldots 0.4 \mathrm{~mm}$. after their irradiation. Interpretation of the spectra was performed in accordance with the correlation tables and guidelines [25]. EMX micro-X spectrometer operating in the $\mathrm{X}$ frequency range, with a modulation frequency of $9.8 \cdot 10^{9} \mathrm{~Hz}(\lambda=3 \mathrm{~cm})$. Samples for analysis were placed in sealed quartz ampoules with a diameter of $3 \mathrm{~mm}$ and a length of $15 \ldots 20 \mathrm{~cm}$, and then the ampoules were placed in an apparatus for research. The concentration of paramagnetic centers and g-factors were determined by the known method [26]. CARL ZEISS SMT AG, Germany, was used to determine the particle size, study the surface topography, structure and phase composition of the composite

$a$

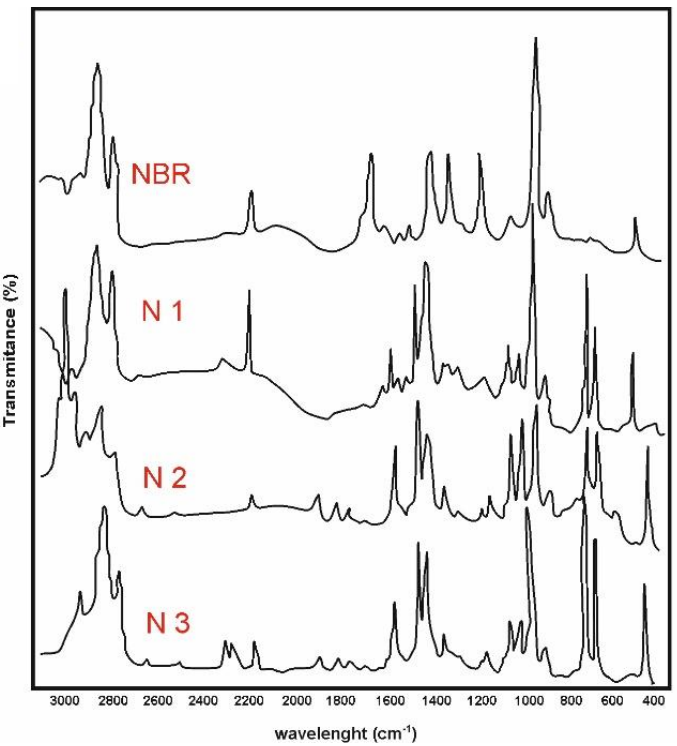

\subsection{MEASUREMENTS}

The IR spectra were recorded on a Fourier FTIR

The spectra of the samples were recorded before and

The EPR measurements were carried out on a Bruker

The Scanning Electron Microscope (SEM) from

material and performed at an accelerating voltage of $20 \mathrm{kV}$ [27].

The study of heat resistance of elastomers was carried out on a Shimadzu TGA/DSC derivatograph-50. The temperature for measurements was set in the range from 0 to $600{ }^{\circ} \mathrm{C}$, heating rate $100{ }^{\circ} \mathrm{C} / \mathrm{min}$. The weight of samples is $5 \mathrm{mg}$, pre-crushed to crumb and placed in crucibles [28].

\section{RESULTS AND DISCUSSION 2.1. FT-IR ANALYSIS}

The IR-FTIR spectra are composites before and after irradiation at $250 \mathrm{kGy}$ absorbed doses which are shown in Fig. 2. After ionization of the films (see Table 2, samples $4,5,6$ ), the decrease is appeared in the intensity of the absorption bands at 1370,1195 , and $1170 \mathrm{~cm}^{-1}$ characteristic for $-\mathrm{SO}_{2} \mathrm{Cl}$ groups, as well as the appearance of a band at $1150 \mathrm{~cm}^{-1}$ related to the sulfonic group $-\mathrm{SO}_{2}$ [29]. FT-IR spectra of $\mathrm{N} \mathrm{1,} 4$ nanocomposite exhibit absorption peaks distinctly at 852,745 , and $456 \mathrm{~cm}^{-1}$ was observed which is attributed to the presence of $\mathrm{ZnO}$ nanoparticles.

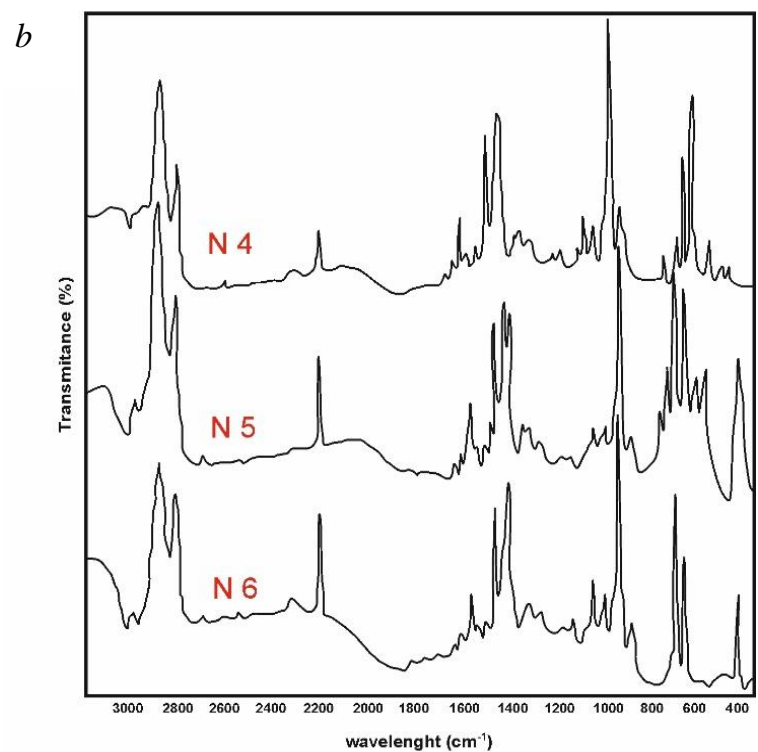

Fig. 2. FTIR spectra of investigated composites simples before (a) and after (b) irradiation 
The optical density of the band at $2230 \mathrm{~cm}^{-1}$, related to the combination of the $-\mathrm{C} \equiv \mathrm{N}$ groups, does not change after irradiation. This suggests show that these groups are not directly involved in the crosslinking reaction.

However, there is an assumption that nitrile groups can activate the adjacent tertiary carbon atom, thereby increasing the number of crosslinked polymer molecules and when stitching NBR with nanosized powder, zinc oxide acts as an acceptor of hydrogen chloride, which is released during the interaction of rubber and vulcanizing agent [30]. Confirmation of this idea is the formation of zinc chloride in the sample during the process of heating the mixture.

Therefore, the process of combining NBR with nanopowders metal oxide, the presence of DSChB and their reactivity are mainly determined by the polar groups $-\mathrm{C} \equiv \mathrm{N}$ and $\mathrm{C}-\mathrm{Cl}$. On this basis, the main attention was paid to the study of the intensity of the stretching vibration band of the nitrile group, located in the $2235 \mathrm{~cm}^{-1}$ area (see Fig. 2,a, N 2) and it is characterized by exceptional stability, both in frequency and shape.

The appearance of a band in the $2240 \mathrm{~cm}^{-1}$ is probably associated with the formation of complex compounds of the $-\mathrm{C} \equiv \mathrm{N}$ groups and metal chlorides. The absorption intensity in the area of $750 \mathrm{~cm}^{-1}$ due to the vibrations of the $\mathrm{C}-\mathrm{Cl}$ bond is noticeably reduced. This indicates that, under irradiation $(250 \mathrm{kGy})$ there is an intense detachment of chlorine from the DSChB molecules [31]. A decrease in the intensity of the $1230 \mathrm{~cm}^{-1}$ band, which lies in the analogous absorption area of FT-IR studies, replaced by aromatic structures, apparently also indicates chlorine removal.

It can be assumed that, according to the viewpoint in the literature, [32] it is known that the introduction into the polymer systems of nanooxide metals $\left(\mathrm{ZnO}, \mathrm{Al}_{2} \mathrm{O}_{3}\right.$, $\left.\mathrm{ZrO}_{2}\right)$ in the process of radiation-chemical reactions, splitting of chlorine atoms from the DSChB molecule, which then interacts with oxide metals and metals, resulting in the formation of branched structures. These results indicate that nanoparticles effectively interact with polymer chains, affecting their vibrational modes and, consequently, their structural and physicochemical properties.

\subsection{ELECTRON PARAMAGNETIC RESONANCE ANALYSIS}

The method of EPR has been used to interpret free radicals quantitatively and qualitatively which were generated by the irradiation of polymeric materials. The form of the line, the width of the line and the position of the line are very important information about the system. Radicals are responsible separate splitting and crosslinking of the chain. Since the free radicals are formed, they are reacting to monomers with the helping of molecules of the greatest radicals.

At last, the free radicals react with the monomers, and thus the chain process develops [33].

In Fig. 3, the EPR spectra of pure NBR and three irradiated nanocomposites have been described. The peaks which are shown with nanocomposites in Fig. 3 (a) are "clearly defined", whereas the spectrum of pure NBR peak is wider and it has a lower intensity.
Reliable research has shown that all three-way radiation nanocomposites have similar EPR signals. The value of g-factor for composites with $\mathrm{ZnO}, \mathrm{Al}_{2} \mathrm{O}_{3}$, and $\mathrm{ZrO}_{2}$ equals to 2.005, 2.008, and 2.009 respectively. Interaction of metal oxides with radicals leads to changes in the reactionary properties of the final and subsequent modes of non-ionic viscosity of kinetic parameters of polymerization and molecular-mass characteristics of macromolecules, synthesized in their contribution.

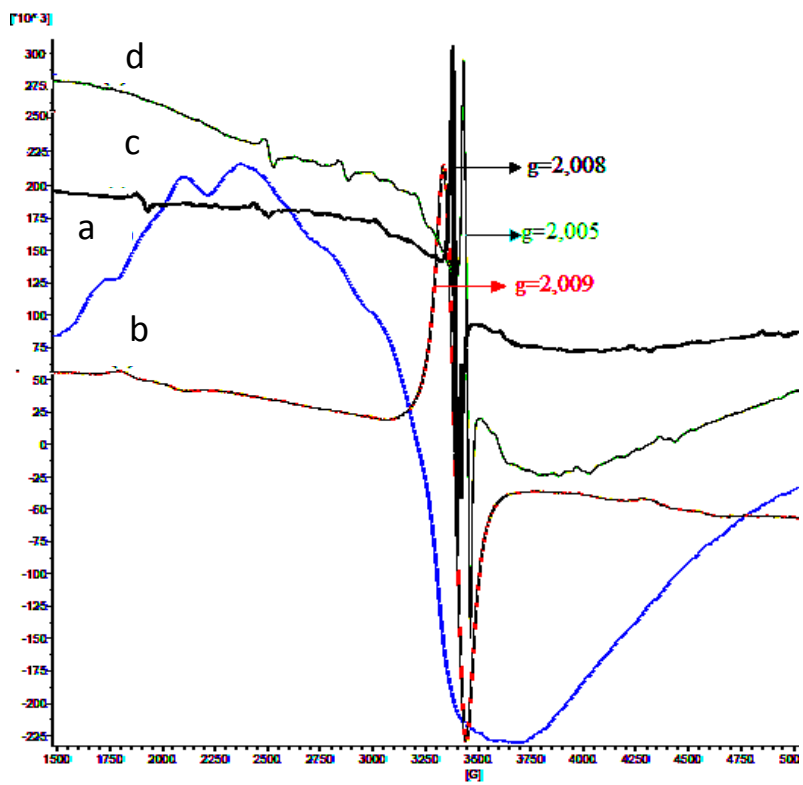

Fig. 3. EPR spectra of pure $\mathrm{NBR}($ a) and irradiated nanocomposites with $\mathrm{ZnO}(b) ; \mathrm{Al}_{2} \mathrm{O}_{3}(c) ; \mathrm{ZrO}_{2}(d)$

The obtained data shows the behavior of the concentration of free radicals depending on the type of metal oxide and also gives an idea of the rates of generation and recombination of free radicals after irradiation with the participation of the DSChB. On time of vulcanization, the concentration of radicals in the elastomeric medium increases, this leads to a decrease of the distance between the two orbits of the unbounded electrons in the orbit of the neighboring radicals. Ionizing radiation produces an excitation of polymer molecules. As a result it forms the recombination of radicals and a single three-dimensional network structure in the elastomer.

\subsection{SCANNING ELECTRON MICROSCOPY ANALYSIS}

The dispersion state of nanoparticles is the key challenge in order to obtain to maximizing the interaction of the nanoparticle interface with the polymer molecules, which, in turn, impacted on improving the overall mechanical properties of nanocomposites.

SEM was mainly used to observe the surface state of a polymer film to assess the dispersion of activator particles in an elastomer before and after irradiation.

According to the results of electron microscopy, nanocomposites consist of isolated electron-contrast nanoparticles $\mathrm{ZnO}, \mathrm{Al}_{2} \mathrm{O}_{3}$, and $\mathrm{ZrO}_{2}$ and they are characterized by a set of needle-like particles and finegrained structures with characteristic sizes of 
$20 \ldots 200 \mathrm{~nm}$, against which agglomerates of up to $800 \mathrm{~nm}$ are noted.

The widest field dispersion is observed for nanocomposites with $\mathrm{ZnO}$ participation before irradiation.

Due to insolubility and the high surface energy of the nanoparticles, the used nanoxides are unevenly distributed and immiscible in the elastomer. As can be seen from figure, nanoparticles are not evenly distributed in the elastomeric matrix. They create microsize accumulations of particles (agglomerates) with a complex structure (Fig. 4) and, therefore, lead to a decrease in their surface area with a subsequent decrease in the interface between the metal oxide and other components. Such agglomerates are visible in all three nanocomposites. These particulates can cause an increase in cross-link density in the vulcanizates, which can degrade the performance properties of the elastomer. On the other hand, it turned out that, after radiation cross-linking with the participation of $\mathrm{DSChB}$, the pattern of nanoparticle distribution in the polymer matrix has been changed and became more equable (Fig. 5). As can be seen from the figures, the radiation treatment of the corresponding samples contributes to the destruction of large agglomerates and the formation of nanoscale particles (less than $200 \mathrm{~nm}$ ).
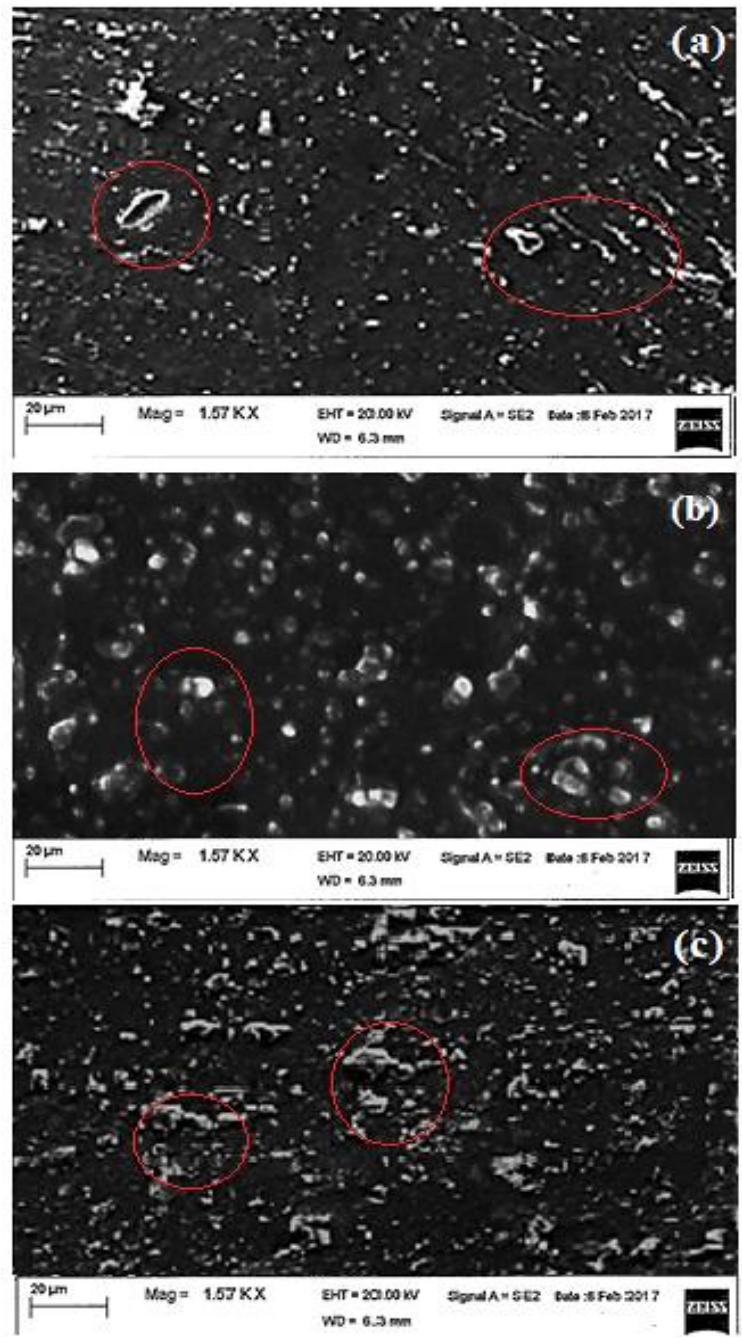

Fig. 4. SEM image of non-irradiated $(\mathrm{ZnO}(a)$, $\left.\mathrm{Al}_{2} \mathrm{O}_{3}(b), \mathrm{ZrO}_{2}(\mathrm{c})\right)$ nanocomposites based on $\mathrm{NBR}$
This change is a result of the influence of nanoparticles of metal oxide on the polymer composition, resulting in the formation of carboncarbon bonds in the presence of DSChB. Additionally, in the process of radiation of the analyzed sample metal chloride is formed, which is capable of participate in activating the process of cross-linking.
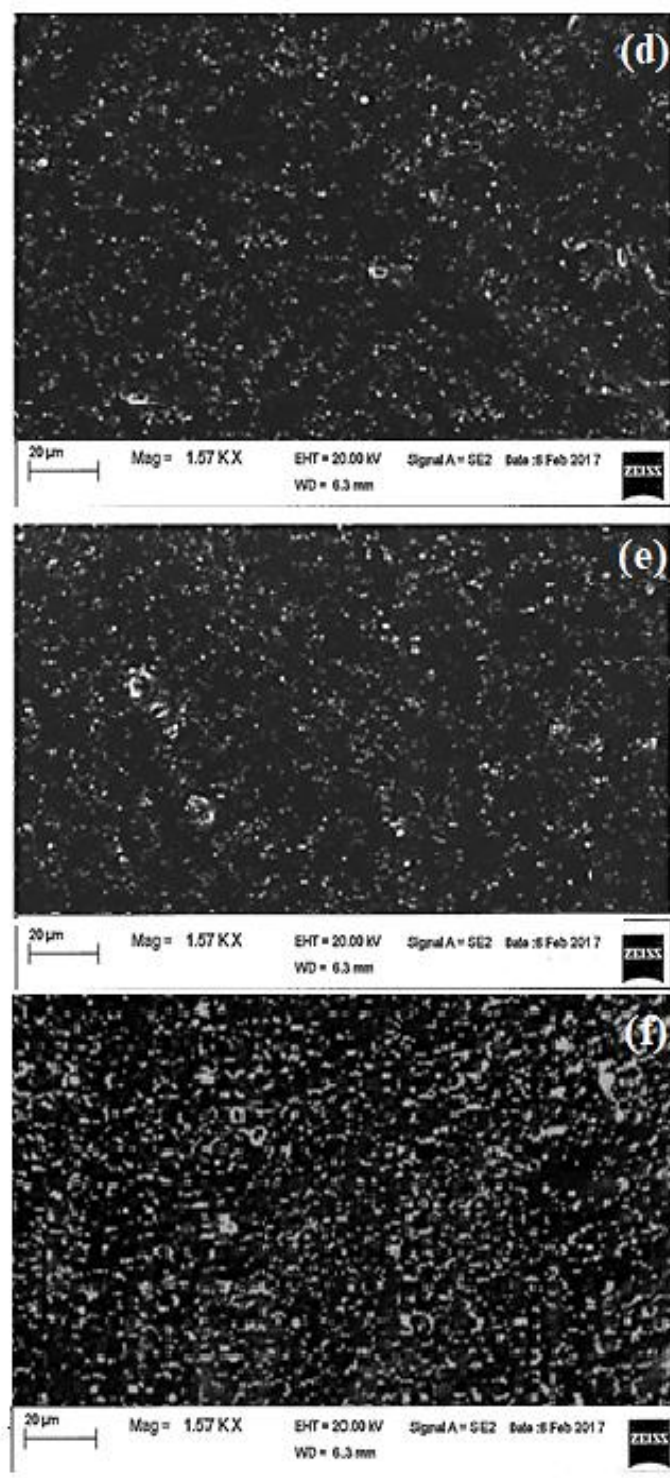

Fig. 5. SEM image of irradiated $\left(\mathrm{ZnO}(d) ; \mathrm{Al}_{2} \mathrm{O}_{3}(e)\right.$; $\left.\mathrm{ZrO}_{2}(f)\right)$ nanocomposites based on NBR

\subsection{TGA/DSC THERMOGRAMS ANALYZER OF NBR NANOCOMPOSITES}

The heat resistance of the obtained nanomaterials based on NBR and the ability to maintain the composition and structure at elevated temperatures was studied using the methods of TGA and DSC in a dynamic mode.

The criteria of heat resistance was the temperature of the initial decomposition of the sample, corresponding to a mass loss of $1 \%$, as well as a loss of 10 and $50 \%$ of the mass, the final decomposition temperature at which the sample was completely decomposed, as well as the effective activation energy of thermal destruction [34]. 

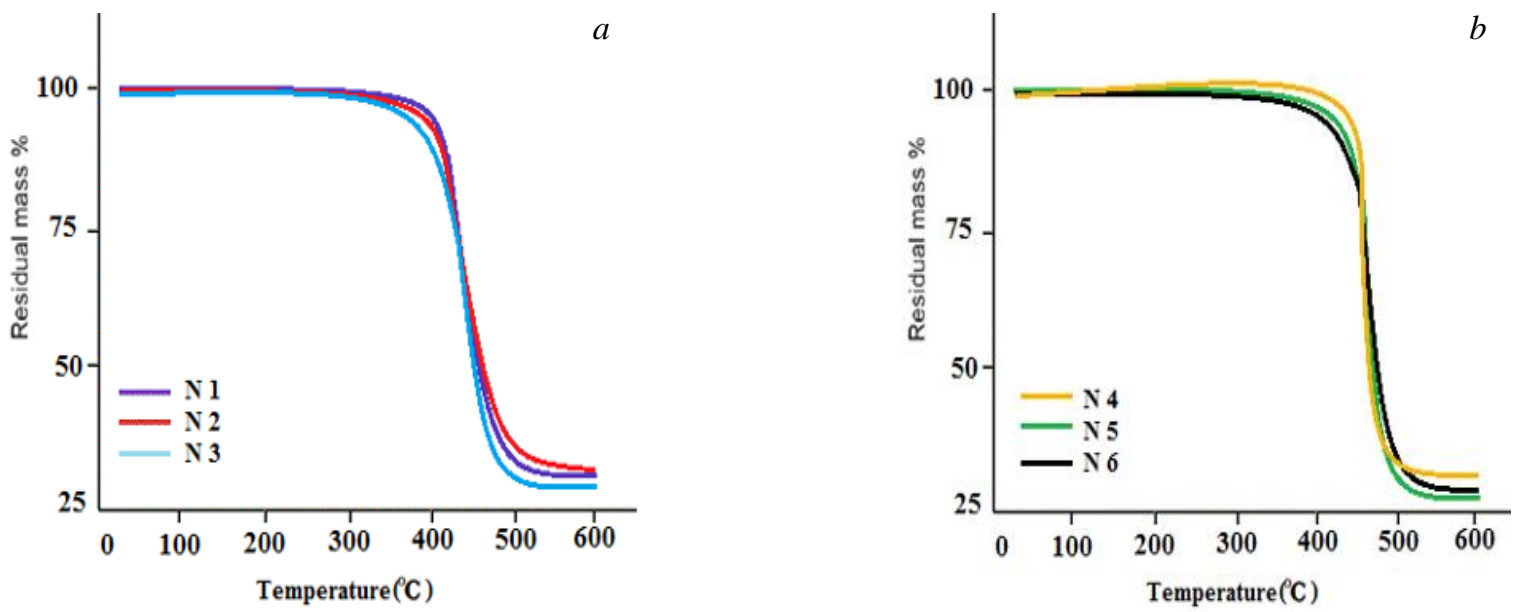

Fig. 6. TGA thermograms of non-irradiated $(a-N 1,2,3)$ and irradiated $(b-N 4,5,6)$
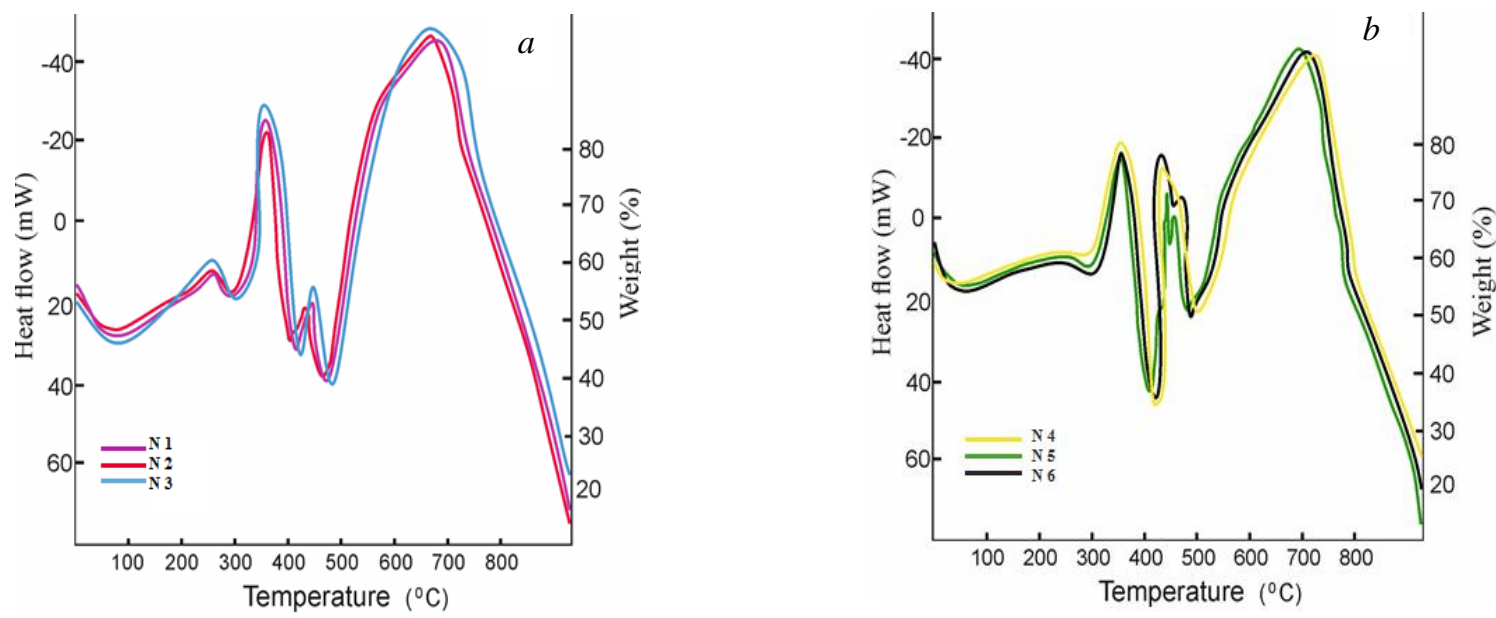

Fig. 7. DSC thermographs of non-irradiated $(a-N 1, N 2, N 3)$ and irradiated $(b-N 4, N 5, N 6)$ nanocomposites based on NBR

The weight derivative of thermogravimetric analysis (TGA) is shown in the curve versus temperature at maximum values of weight loss rate (T90) before and after irradiation for NBR nanocomposites with various metal oxides $\left(\mathrm{ZnO}, \mathrm{Al}_{2} \mathrm{O}_{3}, \mathrm{ZrO}_{2}\right)$.
As can be seen from the Table 3 and shown in diagrams (Figs. 6, 7) T90 increases in irradiated samples compared with non-irradiated NBR based composites.

The data collected from the previous figures, such as the initial, final decomposition temperature and the temperature at half weight loss (T50) are shown in the Table 3.

Table 3

TGA data of unirradiated and irradiated blends

\begin{tabular}{|c|c|c|c|c|}
\hline \multirow{2}{*}{ Sample composition } & \multirow{2}{*}{$\begin{array}{c}\text { Regime of } \\
\text { vulcanization }\end{array}$} & \multicolumn{3}{|c|}{ Temperature loss, ${ }^{\circ} \mathrm{C}$} \\
\hline & & $10 \%$ & $50 \%$ & $90 \%$ \\
\hline NBR/ ZnO/DSChB/ Naphthenic oil & $423 \mathrm{~K} \times 10 \mathrm{~min}$ & 395 & 448 & 513 \\
\hline $\mathrm{NBR} / \mathrm{Al}_{2} \mathrm{O}_{3} / \mathrm{DSChB} / \mathrm{Naphthenic}$ oil & $423 \mathrm{~K} \times 10 \mathrm{~min}$ & 406 & 456 & 529 \\
\hline $\mathrm{NBR} / \mathrm{ZrO}_{2} / \mathrm{DSChB} / \mathrm{Naphthenic} \mathrm{oil}$ & $423 \mathrm{~K} \times 10 \mathrm{~min}$ & 425 & 462 & 536 \\
\hline NBR/ ZnO/DSChB/ Naphthenic oil & $\mathrm{D}=250 \mathrm{kGy}$ & 415 & 471 & 542 \\
\hline $\mathrm{NBR} / \mathrm{Al}_{2} \mathrm{O}_{3} / \mathrm{DSChB} /$ Naphthenic oil & $\mathrm{D}=250 \mathrm{kGy}$ & 417 & 461 & 578 \\
\hline $\mathrm{NBR} / \mathrm{ZrO}_{2} / \mathrm{DSChB} / \mathrm{Naphthenic} \mathrm{oil}$ & $\mathrm{D}=250 \mathrm{kGy}$ & 436 & 492 & 589 \\
\hline
\end{tabular}


As can be seen from Table 3, the participation of $\mathrm{ZrO}_{2}$ in the composition of NBR composites leads to a shift in the temperature of active degradation to a higher temperature region up to $425^{\circ} \mathrm{C}$, whereas for composites with $\mathrm{Al}_{2} \mathrm{O}_{3}$ and $\mathrm{ZnO}$, these data are respectively 406 and $395{ }^{\circ} \mathrm{C}$ for irradiated composites of NBR.

T10 is higher than for non-irradiated composites. This is probably due to the increase in crosslink density. Since it is known that, stitching increases the rigidity of the system, which, in turn, increases the heat resistance of the composite.

The analysis data showed that the initial decomposition temperature, peak temperature, final temperature, and half-weight decomposition temperature behave similarly in all composites, but compared to non irradiated samples, the decomposition temperature shifts to higher values upon irradiation.

Crosslinking and degradation of the elastomer occur simultaneously, but with different ratios of the irradiated composites, since with a high dose of irradiation, the degradation is more pronounced than the crosslinking [35].

\section{CONCLUSION}

The polymer systems are studied the chain macromolecular structures in which low molecular weight compound DSChB was added as a chemical active initiator of vulcanization process, contribute to the formation of the chemical structure $(\mathrm{C}-\mathrm{S}-\mathrm{C} ; \mathrm{C}-\mathrm{C})$ and affect the structural and thermophysical properties of composites based on NBR.

According to the SEM images of samples after irradiated, it has been established that particles of metal oxide are fairly well distributed in the matrix of the NBR, and it is characterized by polarity.

By FT-IR and EPR analysis, it is revealed that the oxides of the metals on which the molecular chains of the elastomer are adsorbed and oriented and the spatial network of the polymer is formed are activated by the influence of radiation.

A comparison between the results obtained with a thermogravimetric analysis, it was found that the introduction of nanoscale metal oxides reduces the mass loss, thereby increasing the heat resistance of butadiene rubbers. The heat resistance of rubbers based on NBR can be significantly improved with the help of heat stabilizers, which use metals in the highest form of valence, which forms stable complexes with chlorinecontaining compounds. The resulting complexes are stable in a certain temperature range, above which they decompose, and the elastomer destructs. Based on the results of the study, the effectiveness of stabilizers based on various metals can be arranged in a row: $\mathrm{Zr}>\mathrm{Zn}>\mathrm{Al}$.

\section{REFERENCE}

1. J. Moczo, B. Pukanszky // J. Ind. Eng. Chem. 2008, N 14, p. 535-563.

2. E. Reynaud, C. Gauthier, J. Perez // J. Revue de Metallurgie. 1999, N 96, p. 169-176.
3. V. Thakur, A. Das, R.N. Mahaling, S. Rooj, U. Gohs, U. Wagenknecht, G. Heinrich // Macromol. Mater. Eng. 2009, N 294, p. 561-569.

4. G. Jiangshan, Y. He, X. Gong, J. Xu // J. Resul. Phys. 2017, N 7, p. 4352-4358.

5. E. A. M. El-Hakim,

A. A. H. Ahmed, G. M. R. A. A. Gomaa, Y. Mohamed // Turk. J. Chem. 2019, N 43, p. 750-759.

6. N. Chen // Polym. Test. 2014, N 23, p. 169-174.

7. A.A. Azeez, K.Y. Rhee, S.J. Park, D. Hui // Comp. Part B: Eng. 2013, N 45, p. 308-320.

8. P. Kiliaris, C.D. Papaspyrides // Prog. Polym. Sci. 2010, N 35, p. 902-958.

9. E. Reynaud, T. Jouen, C. Gauthier, G. Vigier, J. Varlet // Polym. 2001, N 42, p. 2701-2706.

10. W. Hwang, K. Wei, C. Wu // Polym. 2004, N 45, p. 5729-5734.

11. M.A. Islam, M.A.S.R. Saadi // MATTER: Int. J. Sci. Tech. 2018, N 4, p. 137-148.

12. Y. Chen, Z. Peng, L. Kong, M. Fang Huang, L. Wang // Polym. Eng. Sci. 2008, N 48, p. 1674-1677.

13. M. Valera-Zaragoza, A. Yescas-Yescas, E.A. Juarez-Arellano, A. Aguirre-Cruz, A. AparicioSaguilán, E. Ramírez-Vargas // Polym. Bull. 2014, N 71, p. 1295-1313.

14. B. Panampilly, S. Thomas // Polym. Eng. Sci. 2013, N 53, p. 1337-1346.

15. J. Leblanc // Prog. Polym. Sci. 2002, N 27, p. $627-687$

16. A. Omrani, L.C. Simon, A.A. Rostami // Mater. Chem. Phys. 2016, N 114, p. 145-150.

17. Sh. Mammadov, S. Rzayeva, A. Garibov, E. Akperov, J. Mammadov // Am. J. Mat. Sci. 2013, N 2, p. 176-178.

18. G.R. Hamed, K.C. Hua // Rub. Chem. Tech. 2004, N 77, p. 214-226.

19. G. Heideman, Reduced zinc oxide levels in sulphur vulcanisation of rubber compounds: mechanistic aspects of the role of activators and multifunctional additives. Netherlands: "Enschede", 2004, p. 28-94.

20. J.A. Burunkova, I.Yu. Denisyuk, S.A. Semina // J. Nanotech. 2011, N 1, p. 1-6.

21. G. Markovic, M. Marinovic-Cincovic, V. Jovanovic // J. Comp. B: Eng. 2012, N 43, p. 609-615.

22. M. Przybyszewska, M. Zaborski // EXPRESS Polym. Lett. 2009, № 3, p. 542-552.

23. R.F. Khankishiyeva, S.M. Mammadov, M.A. Ramazanov, H.N. Akhundzada // J. Rad. Res. 2017, N 4, p. 5-15.

24. M. Sen, C. Uzun, Ö. Kantoğlu // Nucl. Instrum. Methods Phys. Res. B. 2003, N 208, p. 480484.

25. G. Martiinez-Barrera, H. Lopez, V.M. Castano, R. Rodriiguez // Rad. Phys. Chem. 2004, N 69, p. 155162 .

26. G. Jeschke, G. Panek, S. Schleidt, J. Ulrich // Polym. Eng. Sci. 2004, N 44, p. 1112-1121.

27. F.B. Silva, L.O. Salmazo, E.R. Budemberg, E. Budemberg, R.F. Aroca, M.A. Nobre, E.A. Job // Mat. Sci. For. 2014, N 798-799, p. 426-431. 
28. A.C.O. Gomes, M.G. Oliveira, C.M. Paranhos, B.G. Soares // Rub. Chem.Tech. 2013, N 86(2), p. 286298.

29. S. Chakraborty, S. Bandyopadhyay, R. Ameta, R. Mukhopadhyay, A.S. Deuri // Polym. Test. 2007, N 26, p. 38-41.

30. Sh.M. Mammadov, R.F. Khankishiyeva, D.S. Mammadov, H.N. Akhundzada, A.U. Mahmudova // Am. J. Polym. Sci. 2016, N 6, p. 59-67.

31. Y. Ohtake // J. Soc. Rub. Ind. 2006, N 11, p. 529-536.
32. T. Yasin, S. Ahmed, F. Yoshii, S. Ahmed, K. Makuuchi // React. Funct. Polym. 2002, N 53, p. 173-181.

33. H. Mou, F. Shen, Q. Shi, Y. Liu // Eur. Polym. J. 2012, N 48, p. 857-865.

34. A. Chmielewski, M. Haji-Saeid, S. Ahmed // Nucl. Instrum. Methods Phys. Res. B. 2005, N 236, p. 44-54.

35. M.A. Ramazanov, A.M. Maharramov, S.G. Nuriyeva, U.A. Hasanova, F.V. Hajiyeva // J. Opt. Bio. Mat. 2018, N 10, p. 37-42.

\title{
ИССЛЕДОВАНИЕ ВЛИЯНИЯ ГАММА-ИЗЛУЧЕНИЯ НА СТРУКТУРНЫЕ И ТЕРМОФИЗИЧЕСКИЕ СВОЙСТВА НАНОКОМПОЗИТОВ НА ОСНОВЕ БУТАДИЕН-НИТРИЛЬНОГО КАУЧУКА С УЧАСТИЕМ РАЗЛИЧНЫХ НАНООКСИДОВ МЕТАЛЛОВ
}

\author{
Р.Ф. Ханкиииева, Ш.М. Маммадов, Г.Н. Ахундзаде, Д.М. Маммадов, А.И. Азадалиев, \\ П.И. Исмайилова, Г.А. Маммадова
}

\begin{abstract}
Исследованы структура и термические свойства нанокомпозитов на основе различных нанооксидов металлов $\left(\mathrm{ZnO}, \mathrm{Al}_{2} \mathrm{O}_{3}, \mathrm{ZrO}_{2}\right)$ и ароматических дисульфохлоридных бензольных соединений в матрице бутадиен-нитрильного каучука (БНК), полученного при обработке гамма-излучением. Структурные изменения нанокомпозитов в зависимости от типа использованных наночастиц были исследованы с помощью методов ИК-фурье- и ЭПР-спектроскопии. Для изучения морфологии наночастиц в полимерной матрице и границы раздела фаз в системе полимер-наполнитель использовали сканирующий электронный микроскоп (СЭМ). Кроме того, с помощью термогравиметрического (ТГА)/дифференциального термического анализов (ДТА) были изучены термические свойства образцов на основе БНК. Результаты показывают, что термостабильность нанокомпозитов значительно снижается после облучения, но при добавлении определенного количества бензол-1,3-дисульфонилхлорида (ДСХБ) и наноразмерных оксидов металлов термостойкость смеси каучука может быть улучшена.
\end{abstract}

\section{ДОСЛІДЖЕННЯ ВПЛИВУ ГАММА-ВИПРОМІНЮВАННЯ НА СТРУКТУРНІ I ТЕРМОФІЗИЧНІ ВЛАСТИВОСТІ НАНОКОМПОЗИТІВ НА ОСНОВІ БУТАДІЄН-НІТРИЛЬНОГО КАУЧУКУ ЗА УЧАСТЮ РІЗНИХ НАНООКСИДІВ МЕТАЛІВ}

\section{Р.Ф. Ханкішісва, Ш.М. Маммадов, Г.Н. Ахундзаде, Д.М. Маммадов, А.І. Азадалісв, П.І. Ісмайілова, Г.А. Маммадова}

Досліджено структуру і термічні властивості нанокомпозитів на основі різних нанооксидів металів $(\mathrm{ZnO}$, $\mathrm{Al}_{2} \mathrm{O}_{3}, \mathrm{ZrO}_{2}$ ) і ароматичних дісульфохлорідних бензольних сполук у матриці бутадієн-нітрильного каучуку (БНК), отриманого при обробці гамма-випромінюванням. Структурні зміни нанокомпозитів у залежності від типу використаних наночастинок були досліджені за допомогою методів ІЧ-фур'є- і ЕПР-спектроскопії. Для вивчення морфології наночастинок у полімерній матриці і границі розділу фаз у системі полімернаповнювач використовували скануючий електронний мікроскоп (CEM). Крім того, за допомогою термогравіметричного (ТГА)/диференціального термічного аналізів (ДТА) були вивчені термічні властивості зразків на основі БНК. Результати показують, що термостабільність нанокомпозитів значно знижується після опромінення, але при додаванні певної кількості бензол-1,3-дисульфонілхлориду (ДСХБ) і нанорозмірних оксидів металів термостійкість суміші каучуку може бути поліпшена. 